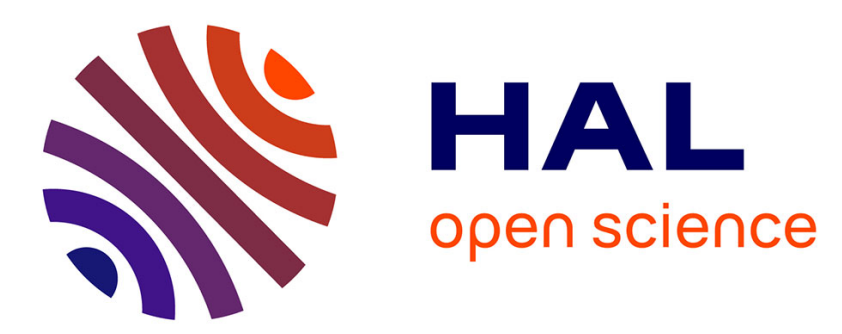

\title{
Correlation of lead, cadmium and mercury levels in tissue and liver samples with age of cattle \\ Mariusz Rudy
}

\section{To cite this version:}

Mariusz Rudy. Correlation of lead, cadmium and mercury levels in tissue and liver samples with age of cattle. Food Additives and Contaminants, 2009, 26 (06), pp.847-853. 10.1080/02652030902835747 . hal-00573879

\section{HAL Id: hal-00573879 \\ https://hal.science/hal-00573879}

Submitted on 5 Mar 2011

HAL is a multi-disciplinary open access archive for the deposit and dissemination of scientific research documents, whether they are published or not. The documents may come from teaching and research institutions in France or abroad, or from public or private research centers.
L'archive ouverte pluridisciplinaire HAL, est destinée au dépôt et à la diffusion de documents scientifiques de niveau recherche, publiés ou non, émanant des établissements d'enseignement et de recherche français ou étrangers, des laboratoires publics ou privés. 


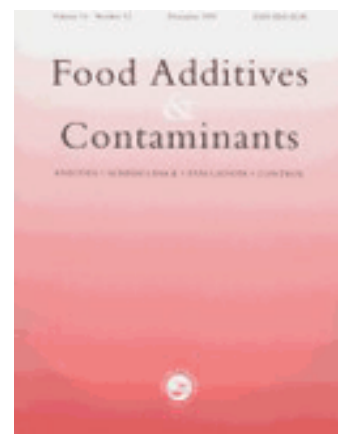

\section{Correlation of lead, cadmium and mercury levels in tissue and liver samples with age of cattle}

\begin{tabular}{|r|l|}
\hline Journal: & Food Additives and Contaminants \\
\hline Manuscript ID: & TFAC-2008-351.R1 \\
\hline Manuscript Type: & Original Research Paper \\
\hline $\begin{array}{r}\text { Date Submitted by the } \\
\text { Author: }\end{array}$ & 17-Feb-2009 \\
\hline Complete List of Authors: & Rudy, Mariusz; Rzeszow University \\
\hline Methods/Techniques: & Metals analysis - AAS \\
\hline Additives/Contaminants: & $\begin{array}{l}\text { Heavy metals, Heavy metals - arsenic, Heavy metals - cadmium, } \\
\text { Heavy metals - mercury }\end{array}$ \\
\hline Food Types: & Animal, Meat \\
\hline
\end{tabular}

\section{SCHOLARONE \\ Manuscripts}




\title{
Correlation of lead, cadmium and mercury levels in tissue and liver samples with age of cattle
}

\author{
Mariusz Rudy \\ Department of Agricultural Processing and Science of Commodities, Biological- \\ Agricultural Faculty, Rzeszów University, ul. Ćwiklińskiej 2, 35-601 Rzeszów, Poland \\ E-mail address: mrudy@univ.rzeszow.pl
}

\begin{abstract}
The aim of the research was to determine the level of accumulation of selected heavy metals $(\mathrm{Pb}, \mathrm{Cd}, \mathrm{Hg}, \mathrm{As})$ in meat and liver of cattle. The animals were divided into four age groups which allowed the analysis of statistical-mathematical correlations between the age of the animals and contamination of meat. The research material for determining the content of heavy metals was taken from the longissimus back muscle ( $m$. longissimus dorsi), and samples of liver from the tail lobe. The analysis carried out shows that contamination of meat of cattle by $\mathrm{Cd}$ and $\mathrm{Pb}$ clearly depends on the age of these animals.
\end{abstract}

Keywords: beef; heavy metals; coefficients of correlation

\section{Introduction}

Among farm animals the ruminants are most exposed to contamination of environment by heavy metals owing to the system of pasture feeding of these animals in the summer period and hay feeding in the winter period. Metals penetrate into grasses most often from the soil and are also present in hay fodder. The differences in the level of contamination of internal organs and muscles by heavy metals depend, among other things, on the species and age of animals (Hecht 1983; Krełowska-Kułas 1994; Studziński et al. 1992) and also on the degree 
of contamination in the region where the animals were bred and their feeds (Barghigiani and Ristori 1994; Sikora 1991; Żebrowska-Rasz 1992). The degree of contamination by heavy metals of the tissue of rabbits (Sikora 1991) and sheep (Studziński et al. 1992), has been studied among three age groups. Other researchers (Hecht 1983; Krełowska-Kułas 1994; Barghigiani and Ristori 1994; Żebrowska-Rasz 1992) have been concerned with contamination by heavy metals of tissues of other species of animals, but did not include the influence of age on the level of accumulation in tissues. In practice cattle are slaughtered more often at the age from 1,5 to 2 years but nevertheless, meat is also obtained from a fewyear-old or even several-year-old animals (e.g. cows).

The aim of our research was to determine the level of accumulation of selected heavy metals $(\mathrm{Pb}, \mathrm{Cd}, \mathrm{Hg}, \mathrm{As})$ in meat and liver of cattle. The animals were divided into four age groups which allowed the analysis of statistical-mathematical correlations between the age of the animals and contamination of meat and liver by these elements. Additionally, the content of the above-mentioned toxicants in tissues of these animals slaughtered in the years $2002-$ 2006, presented in the paper, allows assessment of the degree of contamination by these elements during this period.

\section{Materials and methods}

The research was carried out in the years 2002-2006 on cattle in the region of south-eastern Poland (the areas of Podkarpackie and Lubelskie provinces), coming from the farming areas, with majority of small scale commodity production, practically with no industry. The region of south-east Poland has very good conditions for production of food of high health and nutritional value, since as much as $95 \%$ of soils are of the first class purity in respect of the content of heavy metals (Sucha and Zawada 1994). The concentration of the heavy metals, both in soil as well as in drinking water of this region was within the standard.

For the research there were selected clinically healthy animals, of similar slaughter weight within an age group. The cattle came from individual farms and were fed traditionally (with farm's own fodder).

The slaughter of cattle was carried out in one of meat plants of south-eastern Poland in accordance with the methodology applied by the meat industry. The samples for tests were 
Group I - young slaughter cattle from 1.5 to 2 years,

Group II - middle cattle from 2 to 6 years,

Group III - older cattle from 6 to 12 years,

Group IV - old cattle over 12 years

Samples for determining the content of heavy metals, i.e. arsenic, cadmium, lead and mercury was taken (at least at $100 \mathrm{~g}$ from the same part of each tissue) from a part of the longissimus muscle of back ( $m$. longissimus dorsi) at the level of the last thoracic vertebrae, and samples of liver from the tail lobe. The taken material was lyophilized (FreeZone6L, Labconco) and homogenized .

Samples were mineralized with pressure-microwave method (mineraliser MARS XPRESS, CEM Corporation) in the presence of the mixture of nitric acid and hydrogen peroxide (6/1) according to PN-EN 13805:2003. Simultaneously the whole procedure was carried out for a reagent blanks. The digested solutions were diluted (in such a way so that the measured value of concentration of a given element should be possibly in the centre of the operating range) and there were determined in them: As by atomic absorption spectrometry with generation of hydrides HGAAS according to PN-EN 14627:2005, Pb and $\mathrm{Cd}$ by atomic absorption spectrometry with atomization in graphite furnace FGAAS (SpectrAA 880Z, Varian) according to PN-EN 14084:2004, Hg by cold-vapours with the method of atomic absorption spectrometry according to PN-EN 13806:2003. The content of heavy metals in tissues was expressed in $\mathrm{mg} / \mathrm{kg}$ of fresh mass, taking into account all quantitative processes during preparation of the material and considering reagent blanks .

The blanks were in contact with homogenizer, equipment and containers for similar time as samples. A strict analytical quality control programme was employed during the study, the results of which are presented in table 1. The limits of detection, expressed as a concentration 
in the tissue, was based on the mean sample weight for that tissue type. Quality control of analytical measurements was performed using blank samples and the following certified reference materials: BCR - 185R bovine liver from the Institute for Reference Materials and Measurements for the determination of lead, cadmium, arsenic and NIST - RM 8414 bovine muscle powder from the National Institute of Standards and Technology for the determination of mercury.

Results were subjected to statistical-mathematical analysis which included:

1. Calculation of basic statistical measures of position (arithmetic mean) and the minimum and maximum values were given.

2. One-factor variance analysis which was checked by Tukey's confidence intervals, at to levels of significance $\mathrm{P} \leq 0.01$ and $\mathrm{P} \leq 0.05$. The null hypothesis in variance analysis was verified by the test formulated by Fisher Snedecor (test F).

3. Calculation of the values of coefficients of simple correlation for the purpose of determining the correlation between the content of examined metals in meat and liver of cattle.

Calculations were made basing on the program STATISTICA ver. 6.0.

\section{Results and discussion}

Variability of the chemical composition of beef depends on the sex, degree of musculature and de-fatting of carcasses (Salvini et al. 1998; Williams et al. 1983) and on age, breed or category of cattle (Florek and Litwińczuk 2002; Litwińczuk et al. 1999).

From among farm animals, cattle are the species most susceptible to the effect of heavy metals, especially lead - the element which often is the cause of poisoning with these animals (Monkiewicz and Jaczewski 1990; Żmudzki et al. 1991). Susceptibility of cattle to the toxic effect of $\mathrm{Pb}$ results, among other things, from a long period of pasture feeding during the year. Particularly dangerous is pasturing cows in roadside ditches due to considerable contamination of their flora with lead. 
The quantities of metals $(\mathrm{Cd}, \mathrm{Pb}, \mathrm{Hg}$ and $\mathrm{As})$ in muscles and internal organs of farm animals provide an accurate reflection of the level of these elements in the environment of the animals' breeding and confirm usability of cattle as test organisms of contamination of the production environment (Krupa 1997).

In table 2 the content of heavy metals in tissues of cattle in the years 2002-2006 is given. The data show that the content of cadmium in a muscle fluctuated from $0.012 \mathrm{mg} / \mathrm{kg}$ in 2002 to $0.018 \mathrm{mg} / \mathrm{kg}$ in 2005 , a $50 \%$ increase (differences statistically significant $\mathrm{P} \leq 0.05$ ). The content of mercury both in the muscle as well as in the liver in this period did not exceed $0.001 \mathrm{mg} / \mathrm{kg}$. In the tissues of cattle the presence of arsenic was not detected. In turn, the content of $\mathrm{Pb}$ in beef liver in the years 2002-2004 was about $0.147 \mathrm{mg} / \mathrm{kg}$. The concentration of this element in the liver slightly increased in 2005 by about $6 \%$ and by $25 \%$ in 2006 (however, differences statistically significant $\mathrm{P} \leq 0.05$ occurred only between the years 2002 and 2006). The situation was a bit different in the case of concentration of $\mathrm{Cd}$ in the beef liver. The content of this metal slightly increased in successive years. It should be also noted that the quantity of this element exceeded the permissible level $0.5 \mathrm{mg} / \mathrm{kg}$ (Commission Regulation 466/2001/EC) in as many as four samples of liver.

The average concentrations of lead in muscle of cattle in the years 2002 - 2006 (table 2) were twice the average concentration of domestic level $-0.027 \mathrm{mg} \mathrm{Pb} / \mathrm{kg}$, determined in 1990 for muscles of this species of animals by Żmudzki et al. (1991). Also the average content of $\mathrm{Pb}$ in the liver of cattle in the tested population in all analyzed years turned out to be higher than the level of $0.135 \mathrm{mg} / \mathrm{kg}$ determined by these authors (table 2). In the case of the content of mercury, both in muscles as well as in the liver, higher values (about $0.003 \mathrm{mg} / \mathrm{kg}$ ) than in this paper were obtained by other authors (Krupa 1997; Żmudzki et al. 1991).

The content of heavy metals in tissues of cattle of different age are presented in table 3. The data show that the content of lead in meat of cattle was similar in groups I and II and fluctuated around $0.051-0.054 \mathrm{mg} / \mathrm{kg}$. The quantity of this element increased in comparison with group I by $23 \%$ in group III and by $47 \%$ in group IV. Statistically significant differences were confirmed between groups I and IV, II and IV, and also I and III. However, the content of cadmium in meat $(0.009 \mathrm{mg} / \mathrm{kg})$ was the lowest in group I and increased in successive age groups respectively by: $44 \%$; $55 \%$ and $133 \%$ (high correlation $\mathrm{r}=0.67$ ). 
Statistically significant differences were confirmed only for groups I and IV. In turn, the concentration of mercury in meat and in the liver in particular age groups was lower than $0.001 \mathrm{mg} / \mathrm{kg}$. In the analyzed age groups of cattle there was not stated the presence of arsenic in meat or in the liver. In the case of the content of lead and cadmium in the liver the lowest level was stated in group I respectively: $0.125 \mathrm{mg} / \mathrm{kg}$ and $0.123 \mathrm{mg} / \mathrm{kg}$. The concentration of these metals in the liver increased together with age of animals respectively by: $3 \%$; $15 \%$ - in group II, 13\%; 64\% - in group III, and 43\%; 126\% - in group IV (very high correlation $r \geq 0.80$ ). It should be also noted that for cadmium in the liver there was exceeded the permissible level $(0.5 \mathrm{mg} / \mathrm{kg})$ in two samples in group IV and in one case in group III.

In the research of Krupa et al. (1995) concerning the concentration of cadmium in tissues of cattle of the region of south-eastern Poland the differences in quantities of this metal in muscles and organs of cows and young cattle turned out to be statistically irrelevant. The level of accumulation of $\mathrm{Cd}$ in tissues of young cattle and cows at that time was respectively: in muscles 0.016 and $0.021 \mathrm{mg} / \mathrm{kg}$, in the liver 0.262 and $0.331 \mathrm{mg} / \mathrm{kg}$. And in kidneys it was significantly higher than in muscles and in the liver, constituting respectively: 0.836 and $1.212 \mathrm{mg} / \mathrm{kg}$. In other research of this author (Krupa 1997) on bulls of the age of $18-22$ months there were obtained higher values of the content of cadmium in meat $(0.023 \mathrm{mg} / \mathrm{kg})$, and also of the content of mercury in meat $(0.003 \mathrm{mg} / \mathrm{kg})$ and in the liver $(0.0037 \mathrm{mg} / \mathrm{kg})$ than in this paper (table 3) for the same age group of animals. In turn, this author obtained in cattle smaller quantities of lead in the liver $(0.077 \mathrm{mg} / \mathrm{kg})$ and the concentration of lead in meat $(0.049 \mathrm{mg} / \mathrm{kg})$ and cadmium in the liver $(0.115 \mathrm{mg} / \mathrm{kg})$ at similar level as in this paper. The same author in the research (Krupa et al. 1994; 1995) concerning the assessment of accumulation of lead in tissues of young cattle and cows of the region of south-eastern Poland did not observe significant differences in respect of the quantity of $\mathrm{Pb}$ in muscles and kidneys, however, significantly more of this metal accumulated in livers of older specimens. During the research presented in quoted papers there also was not stated a dependence on this factor despite noting some differentiation of the level of $\mathrm{Hg}$ with younger and older specimens.

Wałkuska and Saddour (1992), however, indicate definitely higher concentration of lead in the liver of young beef cattle $(0.64 \mathrm{mg} / \mathrm{kg})$ and cows $(0.77 \mathrm{mg} / \mathrm{kg})$, and lower with calves (0.018 mg/kg). Salisbury and Chan (1991), assessing in the years 1982-1989 in this respect the livers and kidneys of young fattening beef cattle in Canada, present as average values for 
this population the following ones respectively: 0.07 and $0.11 \mathrm{mg} / \mathrm{kg} \mathrm{Pb}$, and for calves a bit higher since amounting to 0.10 and $0.15 \mathrm{mg} / \mathrm{kg}$.

Similar as in this paper (table 3$)$ content of lead $(0.050 \mathrm{mg} / \mathrm{kg})$ and cadmium $(0.004 \mathrm{mg} / \mathrm{kg})$ in meat of young slaughter cattle was obtained by Doganoc (1996). However, a lower quantity of these elements respectively: $(0.005-0.015 \mathrm{mg} / \mathrm{kg})$ and $(0.001-0.002 \mathrm{mg} / \mathrm{kg})$ in beef was obtained by other authors (Gonzales-Weller 2006; Jorhem et al. 1991; Larsen et al. 2002; López et al. 2000; Niemi et al. 1991; Tahvonen and Kumpulainen 1994). In turn, López et al. (2002) found a bit higher quantities of $\mathrm{Pb}, \mathrm{Cd}$ and $\mathrm{As}$ in beef than in veal respectively: 0.017; $0.009 \mathrm{mg} \mathrm{Pb} / \mathrm{kg}, 0.0014 ; 0.0013 \mathrm{mg} \mathrm{Cd} / \mathrm{kg}$ and 0.005; $0.004 \mathrm{mg} \mathrm{As} / \mathrm{kg}$.

In the research of Krupa et al. (1994) on concentration of arsenic in tissues of cattle there was stated its presence at the level of thousandth parts of $\mathrm{mg} \mathrm{As} / \mathrm{kg}$. In this research there were not shown significant differences between the quantity of this element in muscles and in kidneys and age. However, this factor decided on significantly higher level of arsenic in livers of older animals $(0.0097 \mathrm{mg} / \mathrm{kg})$ than in young cattle $(0.0065 \mathrm{mg} / \mathrm{kg})$. In turn, with the cattle of Krośnieńskie and Rzeszowskie provinces examined by the same team of authors (Krupa et al. 1995), and slaughtered at the age of 13-18 months and at the age of 7-11 years, a slightly higher level of this metal was stated in muscles $(0.0056 \mathrm{mg} / \mathrm{kg})$ and in the liver $(0.0112$ $\mathrm{mg} / \mathrm{kg}$ ) of young specimens. With cows there was a bit less of arsenic, respectively: 0.0045 and $0.0086 \mathrm{mg} / \mathrm{kg}$. The reverse dependence occurred in contamination of kidneys by this metal, in which the quantities of arsenic were higher than in meat and in the liver, with young cattle amounting on average to $0.0102 \mathrm{mg} / \mathrm{kg}$, and in cows $0.0119 \mathrm{mg} / \mathrm{kg}$ (Krupa et al. 1995).

Correlative dependences between the content of heavy metals in tissues of cattle were presented in table 4 . The data show that the biggest dependence occurred between the content of lead in the liver and in meat $(r=0.95)$, between the concentration of cadmium in the liver and in meat $(\mathrm{r}=0.91)$, and also between the quantity of $\mathrm{Cd}$ and $\mathrm{Pb}$ in meat $(\mathrm{r}=0.93)$. However, a bit lower correlative dependencies occurred in the following pairs $\mathrm{Cd}$ in liver $-\mathrm{Pb}$ in liver $(\mathrm{r}=0.89), \mathrm{Pb}$ in liver $-\mathrm{Cd}$ in meat $(\mathrm{r}=0.87)$, and also $\mathrm{Hg}$ in liver $-\mathrm{Hg}$ in meat $(\mathrm{r}=0.62)$. Żarski et al. (1994) assessing the content of mercury in tissues of young cattle obtained the strongest relation between the content of $\mathrm{Hg}$ in liver and muscles $(\mathrm{r}=$ 0.62). Krupa (1997), however, stated that in tissues of cattle the significant correlations occurred most often between the content of cadmium and lead and the content of mercury and 
arsenic. From among the essential coefficients of correlation the highest correlation ( $\mathrm{r}$ from 0.80 to 0.87 ) was obtained by this author between the content of lead and cadmium in muscles. In turn, he noted a significant but negative correlation between the content of cadmium and the content of mercury in tissues of cattle ( $\mathrm{r}=$ from -0.40 to -0.48$)$.

\section{Conclusions}

The contamination of meat of cattle by $\mathrm{Cd}$ and $\mathrm{Pb}$ clearly depends on the age of these animals. In muscles and in the liver of the animals arsenic was not detected above 0.001 $\mathrm{mg} / \mathrm{kg}$. However, the average concentration of mercury in these tissues was similar $(\leq 0.001$ $\mathrm{mg} / \mathrm{kg}$ ) in all age groups of cattle. Three samples exceeded the maximum permissible concentration of cadmium in the liver of cattle of age groups III and IV. The livers from these age groups should be used for consumption only to a limited extent. Between the content of lead and cadmium in the liver and the concentration of these elements in muscles there occurred very high positive correlative dependence.

\section{References}

Barghigiani C., Ristori T. 1994. Mercury levels in agricultural products of Mt. Amiata (Tuscany, Italy). Archiv. Emdron. Contam. Toxicol., 26, 3, 329-334.

Commission Regulation 466/2001/EC of 8 March 2001 setting maximum levels for certain contaminants in foodstuffs. O. J. 2001, L 77, 1-13.

Doganoc D. Z. 1996. Lead and cadmium concentrations in meat, liver and kidney of Slovenian cattle and pigs from 1989 to 1993. Food Additives and Contaminants 13, 237-241.

Florek M., Litwińczuk Z. 2002. The quality of meat from carcasses of young bulls and heifers classified according to the EUROP system. Anim. Sci. Papers Rep. 20, suppl. 1, 169-178.

Gonzalez - Weller D., Karlsson L., Caballero A., Hernandez F., Gutierrez A., Gonzalez - Iglesias T., Marino M., Hardisson A. 2006. Lead and cadmium in meat and meat products consumer by the population in Tenerife Island, Spain. Food Additives and Contaminants 23(8): 757-763.

Hecht H. 1983. Toxische Schwermetalle in Fleisch und Innereien verschiedener Tierarten. Fleischwirtschaft, 4, 544-558.

Jorhem L., Slorach S., Sundstrom B., Ohlin B. 1991. Lead, cadmium, arsenic and mercury in meat, liver and kidney of Swedish pigs and cattle in 1984-1988. Food Additives and Contaminants 8, 201-211. 
Krełowska-Kułas M. 1994. Zanieczyszczenia chemiczne surowców i żywności pochodzenia zwierzęcego. Mater. 25 Sesji Nauk. „Postępy w technologii żywności", Lublin 15-16.09.1994. AR w Lublinie, 237.

Krupa J. 1997. Badania bioakumulacji toksycznych metali ciężkich w mięśniach i narządach wewnętrznych zwierząt gospodarskich z południowo - wschodniego makroregionu Polski. Zeszyty Naukowe AR Kraków. Rozprawy nr 220. Kraków.

Krupa J., Zin M., Szmulik A. 1994. Ocena zawartości niektórych metali ciężkich w tkankach bydła i koni z regionu południowo-wschodniej Polski. Prace Towarzystwa Naukowego w Rzeszowie, 2, $35-43$.

Krupa J., Zin M., Szmulik A. 1995. Pozostałości pestycydów i niektórych metali ciężkich (Cd, Pb, As i Hg) w tkankach bydła. Mater. Symp. Nauk. Kierunki rozwoju chowu i hodowli bydła rzeźnego. Rzeszów 10-11.09.1996. Filia AR w Rzeszowie, 49-59.

Larsen E. H., Andersen N. L., Møller A., Petersen A., Mortensen G. K., Petersen J. 2002. Monitoring the content and intake of trace elements from food in Denmark. Food Additives and Contaminants $19,33-46$.

Litwińczuk A., Litwińczuk Z., Barłowska J., Florek M., Pieróg M. 1999. Variability of beef chemical composition with regard to some factors determining it. Part II. Protein and fat content. Annales UMCS, 17, 99-104.

López Alonso M., Benedito J. L., Miranda M., Castillo C., Hernandez J., Shore R. F. 2000. Toxic and trace elements in liver, kidney and meat from slaughtered in Galicia (NW Spain). Food Additives and Contaminants 17, 447-457.

López Alonso M., Benedito J. L., Miranda M., Castillo C., Hernandez J., Shore R. F. 2002. Contribution of cattle products to dietary intake of trace and toxic elements in Galicia, Spain. Food Additives and Contaminants, 19, 6, 533-541.

Monkiewicz J., Jaczewski S. 1990. Rozmieszczenie ołowiu w tuszy dzików w zależności od odległości od rany postrzałowej. Medycyna Weterynaryjna, 46, 6, 187-188.

Niemi A., Venalainen E. R., Hirvi T., Hirn J., Karppanen E. 1991. The lead, cadmium and mercury concentrations in muscle, liver and kidney from Finnish pigs and cattle during 1987-1988. Zeitschrift fuer Lebensmittel Untersuchung und Forschung 192, 427-429.

PN-EN 13805:2003. Foodstuffs - Determination of trace elements - Pressure digestion. Polish Committee for Standardization.

PN-EN 14627:2005. Foodstuffs - Determination of trace elements - Determination of total arsenic and selenium by hydride generation atomic absorption spectrometry (HGAAS) after pressure digestion. Polish Committee for Standardization.

PN-EN 14084:2004. Foodstuffs - Determination of trace elements - Determination of lead, cadmium, zinc, copper and iron by atomic absorption spectrometry (AAS) after microwave digestion. Polish Committee for Standardization. 
PN-EN 13806:2003. Foodstuffs - Determination of trace elements - Determination of mercury by cold-vapour atomic absorption spectrometry (AAS) after pressure digestion. Polish Committee for Standardization.

Salisbury D.C., Chan W. 1991. Multielement concentrations in liver and kidney tissues from five species of Canadian slaughter animals, J. Assoc. Off. Anal. Chem., 74,4, 587-591.

Salvini S., Parpinel M., Gnagnarella P., Maisonneuve P.. Turrini A. 1998. [w:] Banca dati di composizione degli alimenti per studi epidemiologici in Italia. Instituto Europeo di Oncologia, Milano, Italy, 958.

Sikora T. 1991. Kadm i ołów w mięśniach oraz wątrobie królików z terenu aglomeracji krakowskiej. Przemysł Spożywczy, 8, 199-200.

Studziński T., Wałkuska G., Saddour A. 1992. Stężenie ołowiu, kadmu, miedzi i cynku w wątrobie, nerkach, mięśniach szkieletowych i mózgowiu jagniąt i owiec dorosłych. Bromat. Chem. Toksykol., 25, 4, 355-360.

Sucha M., Zawada A. 1994. Stan środowiska w województwie rzeszowskim w 1993 roku Wojew. Inspekt. Ochrony Środ., Bibliot. Monit. Śród., Rzeszów.

Tahvonen R., Kumpulainen J. 1994. Lead and cadmium contents in pork, beef and chicken, and in pig and cow liver in Finland during 1991. Food Additives and Contaminants 11, 415-426.

Wałkuska G., Saddour A. 1992. Stężenie ołowiu, kadmu, miedzi i cynku w mózgowiu, płynie mózgowo-rdzeniowym, wątrobie, żółci i krwi u bydła z okolic Lublina. Bromat. Chem. Toksykol., $25,4,349-354$.

Williams J. E., Wagner D. G., Walters L. E., Horn G W., Waller G. R., Sims P. L., Guenther J. J. 1983. Effect of production systems on performance, body composition and lipid and mineral profiles of soft tissue in cattle. J. Anim. Sci., 57,1020-1024.

Żarski T. P., Dębski B., Samek M. 1994. Stężenie rtęci w tkankach młodego bydła rzeźnego importowanego z Litwy. Medycyna Weterynaryjna, 50, 2, 77-79.

Żebrowska-Rasz H. 1992. Zanieczyszczenia chemiczne w tkankach zwierząt i żywności pochodzenia zwierzęcego. Przegląd Hodowlany, 10, 1-5.

Żmudzki J., Szkoda J., Juszkiewicz T. 1991. Stężenia pierwiastków śladowych w tkankach bydła w Polsce. Medycyna Weterynaryjna, 47, 9, 413-416. 
Table 1. Results of the analytical quality control programme used in the determination of cadmium $(\mathrm{Cd})$, lead $(\mathrm{Pb})$, mercury $(\mathrm{Hg})$ and arsenic (As) in bovine samples

\begin{tabular}{|c|c|c|c|c|}
\hline $\begin{array}{c}\text { Quality } \\
\text { characteristics }\end{array}$ & $\mathrm{Pb}$ & $\mathrm{Cd}$ & As & $\mathrm{Hg}$ \\
\hline \multicolumn{5}{|l|}{$\begin{array}{l}\text { Detection limit in } \\
\text { samples }(\mathrm{mg} / \mathrm{kg})\end{array}$} \\
\hline Muscle & 0.006 & 0.001 & 0.001 & 0.0001 \\
\hline \multirow[t]{2}{*}{ Liver } & 0.012 & 0.002 & 0.001 & 0.0001 \\
\hline & $\begin{array}{r}\text { Certified R } \\
\text { BC } \\
(\text { Bo }\end{array}$ & $\begin{array}{l}\text { ce Material } \\
5 \mathrm{R} \\
\text { ver) }\end{array}$ & & $\begin{array}{c}\text { NIST - Reference } \\
\text { Material } 8414 \\
\text { (Bovine Muscle } \\
\text { Powder) }\end{array}$ \\
\hline $\begin{array}{l}\text { Measured mean } \pm \\
\quad \mathrm{SD}(\mathrm{mg} / \mathrm{kg})\end{array}$ & $0.163 \pm 0.008$ & $0.526 \pm 0.019$ & $0.029 \pm 0.003$ & $0.0045 \pm 0.0005$ \\
\hline $\begin{array}{l}\text { Certified mean } \pm \\
\mathrm{SD}(\mathrm{mg} / \mathrm{kg})\end{array}$ & $0.172 \pm 0.009$ & $0.544 \pm 0.017$ & $0.033 \pm 0.002$ & $0.005 \pm 0.003$ \\
\hline Recovery (\%) & 94.8 & 96.7 & 87.9 & 90.0 \\
\hline $\begin{array}{l}\text { Relative standard } \\
\text { deviation }(\%)\end{array}$ & 5 & 4 & 10 & 11 \\
\hline
\end{tabular}


Table 2. The content of heavy metals in meat and liver of cattle in the years 2002-2006 (mg/kg)

\begin{tabular}{|c|c|c|c|c|c|c|c|c|c|c|c|c|c|c|c|c|}
\hline \multirow{2}{*}{ Specification } & \multicolumn{3}{|c|}{2002} & \multicolumn{3}{|c|}{2003} & \multicolumn{3}{|c|}{2004} & \multicolumn{3}{|c|}{2005} & \multicolumn{3}{|c|}{2006} & \multirow{2}{*}{$\begin{array}{c}\text { The significance of } \\
\text { differences }\end{array}$} \\
\hline & $\bar{x}$ & $\mathrm{x}_{\min }$ & $\mathrm{x}_{\max }$ & $\bar{x}$ & $\mathrm{x}_{\min }$ & $\mathrm{x}_{\max }$ & $\bar{x}$ & $\mathrm{x}_{\min }$ & $\mathrm{x}_{\max }$ & $\bar{x}$ & $\mathrm{x}_{\min }$ & $\mathrm{x}_{\max }$ & $\bar{x}$ & $\mathrm{x}_{\min }$ & $\mathrm{x}_{\max }$ & \\
\hline \multicolumn{17}{|l|}{ Meat: } \\
\hline $\mathrm{Pb}$ & 0.060 & 0.047 & 0.069 & 0.062 & 0.052 & 0.072 & 0.062 & 0.051 & 0.073 & 0.066 & 0.057 & 0.089 & 0.060 & 0.041 & 0.086 & \multirow{4}{*}{$2002<2005 *$} \\
\hline $\mathrm{Cd}$ & 0.012 & 0.006 & 0.015 & 0.015 & 0.007 & 0.021 & 0.016 & 0.007 & 0.019 & 0.018 & 0.009 & 0.031 & 0.015 & 0.005 & 0.034 & \\
\hline $\mathrm{Hg}$ & $<0.001$ & $<0.001$ & $<0.001$ & $<0.001$ & $<0.001$ & $<0.001$ & $<0.001$ & $<0.001$ & $<0.001$ & $<0.001$ & $<0.001$ & $<0.001$ & 0.001 & 0.001 & 0.001 & \\
\hline As & nd & nd & nd & nd & nd & nd & nd & nd & nd & nd & nd & nd & nd & nd & nd & \\
\hline \multicolumn{17}{|l|}{ Liver: } \\
\hline $\mathrm{Pb}$ & 0.147 & 0.079 & 0.209 & 0.148 & 0.083 & 0.271 & 0.148 & 0.071 & 0.302 & 0.156 & 0.087 & 0.389 & 0.183 & 0.097 & 0.445 & \multirow[t]{4}{*}{$2002<2006 *$} \\
\hline $\mathrm{Cd}$ & 0.159 & 0.024 & 0.434 & 0.172 & 0.098 & 0.478 & 0.189 & 0.121 & 0.594 & 0.200 & 0.098 & 0.558 & 0.191 & 0.082 & 0.378 & \\
\hline $\mathrm{Hg}$ & $<0.001$ & $<0.001$ & $<0.001$ & $<0.001$ & $<0.001$ & $<0.001$ & $<0.001$ & $<0.001$ & $<0.001$ & $<0.001$ & $<0.001$ & $<0.001$ & 0.001 & 0.001 & 0.002 & \\
\hline As & nd & nd & nd & nd & nd & nd & nd & nd & nd & nd & nd & nd & nd & nd & nd & \\
\hline
\end{tabular}

Explanation:

nd - presence not stated:

- As over $0.001 \mathrm{mg} / \mathrm{kg}$;

* - differences significant at $\mathrm{P} \leq 0.05$. 
Table 3. The content of heavy metals in meat and liver of cattle of different age (mg/kg)

\begin{tabular}{|c|c|c|c|c|c|c|c|c|c|c|c|c|c|c|}
\hline \multirow{3}{*}{ Specification } & \multicolumn{12}{|c|}{ Groups } & \multirow{3}{*}{$\mathrm{r}$} & \multirow{3}{*}{$\begin{array}{c}\text { The significance of } \\
\text { differences }\end{array}$} \\
\hline & \multicolumn{3}{|c|}{$\mathrm{I}$} & \multicolumn{3}{|c|}{ II } & \multicolumn{3}{|c|}{ III } & \multicolumn{3}{|c|}{ IV } & & \\
\hline & $\bar{x}$ & $\mathrm{x}_{\min }$ & $\mathrm{x}_{\max }$ & $\bar{x}$ & $\mathrm{x}_{\min }$ & $\mathrm{x}_{\max }$ & $\bar{x}$ & $\mathrm{x}_{\min }$ & $\mathrm{x}_{\max }$ & $\bar{x}$ & $\mathrm{x}_{\min }$ & $\mathrm{x}_{\max }$ & & \\
\hline \multicolumn{15}{|l|}{ Meat: } \\
\hline $\mathrm{Pb}$ & 0.051 & 0.047 & 0.067 & 0.054 & 0.050 & 0.076 & 0.063 & 0.052 & 0.075 & 0.075 & 0.053 & 0.089 & $0.72 *$ & $\begin{array}{c}\mathrm{I}<\mathrm{IV}^{* *} ; \mathrm{II}<\mathrm{IV}^{* *} ; \\
\mathrm{I}<\mathrm{III} *\end{array}$ \\
\hline $\mathrm{Cd}$ & 0.009 & 0.006 & 0.019 & 0.013 & 0.007 & 0.021 & 0.014 & 0.010 & 0.023 & 0.021 & 0.010 & 0.031 & $0.67 *$ & $\mathrm{I}<\mathrm{IV} * *$ \\
\hline $\mathrm{Hg}$ & $<0.001$ & $<0.001$ & $<0.001$ & $<0.001$ & $<0.001$ & $<0.001$ & $<0.001$ & $<0.001$ & $<0.001$ & $<0.001$ & $<0.001$ & $<0.001$ & - & - \\
\hline As & nd & nd & nd & nd & nd & nd & nd & nd & nd & nd & nd & nd & - & - \\
\hline Liver: & & & $+\sqrt{2}$ & & & & & & & & & & & \\
\hline $\mathrm{Pb}$ & 0.125 & 0.079 & 0.141 & 0.129 & 0.047 & 0.240 & 0.141 & 0.097 & 0.302 & 0.179 & 0.121 & 0.389 & $0.83^{*}$ & $\mathrm{I}<\mathrm{IV} * * ; \mathrm{I}<\mathrm{III} *$ \\
\hline $\mathrm{Cd}$ & 0.123 & 0.025 & 0.481 & 0.141 & 0.110 & 0.491 & 0.202 & 0.013 & 0.528 & 0.278 & 0.016 & 0.558 & $0.80^{*}$ & $\begin{array}{c}\mathrm{I}<\mathrm{IV} \mathrm{V}^{* *} ; \mathrm{II}<\mathrm{IV} \mathrm{IV}^{* *} \\
\mathrm{I}<\mathrm{III} *\end{array}$ \\
\hline $\mathrm{Hg}$ & $<0.001$ & $<0.001$ & $<0.001$ & $<0.001$ & $<0.001$ & $<0.001$ & $<0.001$ & $<0.001$ & $<0.001$ & $<0.001$ & $<0.001$ & $<0.001$ & - & - \\
\hline As & nd & nd & nd & nd & nd & nd & nd & nd & nd & nd & nd & nd & - & - \\
\hline
\end{tabular}

Explanation:

nd - presence not stated:

- As over $0.001 \mathrm{mg} / \mathrm{kg}$;

* - differences significant at $\mathrm{P} \leq 0.05$.

** - differences significant at $\mathrm{P} \leq 0.01$. 
Table 4. Coefficients of simple correlation between the content of heavy metals in meat and liver of cattle

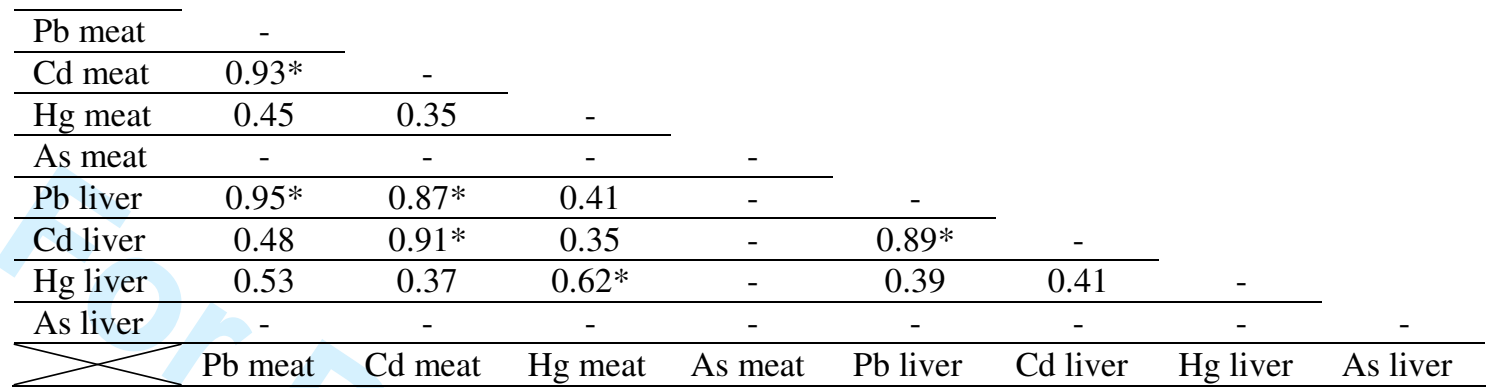

* - coefficients significant at $\mathrm{P} \leq 0.05$ 